\title{
Fibrin D-dimer impairs the accumulation and anticoagulant properties of heparan sulphate and stimulates secretion of plasminogen activator inhibitor-1 by rabbit coronary endothelial cells ${ }^{\star \star}$
}

Natalia Yu. Yevdokimova ${ }^{\bowtie}$, Larisa D. Veselovska, Genrietta K. Gogolinska, Olexandra M. Buchanevich, Galina V. Kosyakova, Pavel G. Gritsenko, Eduard V. Lugovskoj and Sergiy V. Komisarenko

\section{Institute of Biochemistry, National Academy of Sciences of Ukraine, Kiev, Ukraine}

Received: 27 November, 2002; revised: 30 January, 2003; accepted: 24 February, 2003

Key words: fibrin D-dimer, heparan sulphate, plasminogen activator inhibitor-1, endothelial cells

\begin{abstract}
Fibrin split product D-dimer (DD) is most probably involved in the development of vascular disorders. At $1.5 \mu \mathrm{M}$ concentration DD inhibited the incorporation of $\mathrm{D}-\left[1-{ }^{3} \mathrm{H}\right]$ glucosamine hydrochloride and $\left[2-{ }^{14} \mathrm{C}\right]$ acetate $\cdot \mathrm{Na}$ into pericellular heparan sulphate (HS) of rabbit coronary endothelial cells without affecting other groups of glycosaminoglycans (GAGs). At the same time, DD reduced HS ability to bind antithrombin (AT) and suppressed NO production. The effect of DD on pericellular GAGs was similar to that of $N^{\omega}$-methyl-L-arginine, the competitive inhibitor of endothelial NO synthase (eNOS). L-Ascorbic acid, eNOS activator, increased the level of endogenous NO in the DD-treated cells, and restored HS accumulation and antithrombin binding. It is suggested that DD influence on endothelial HS may be mediated by NO production. Another effect of DD, namely, stimulation of plasminogen activator inhibitor-1 (PAI-1) secretion did not depend on the NO level. The decreased
\end{abstract}

\footnotetext{
${ }^{\star}$ Preliminary results were presented at the XVIII Congress of the International Society on Thrombosis and Haemostasis, July, 2001, Paris, France.

This work was supported by the National Academy of Sciences of Ukraine and partly by the Wellcome Trust Travelling Research Grant.

${ }^{\circledR}$ To whom correspondence should be addressed: Dr. Natalia Yu. Yevdokimova, Institute of Biochemistry, 9 Leontovicha Str., 01030 Kyjv, Ukraine; tel (380) (44) 550 7114; fax (380) (44) 229 6365; e-mail: berezan@mathber.carrier.kiev.ua

Abbreviations: AT, antithrombin; CS, chondroitin sulphate; DD, fibrin D-dimer; DS, dermatan sulphate; GAG, glycosaminoglycan; GlcNAc, $\mathrm{N}$-acetyl-D-glucosamine; $\mathrm{GlcNSO}_{3}, \mathrm{~N}$-sulpho-D-glucosamine; ECM, extracellular matrix; HA, hyaluronic acid; HS, heparan sulphate; Fg, fibrinogen; ICAM-1, intercellular adhesion molecule-1; L-NMMA, $N$-methyl-L-arginine; eNOS, endothelial nitric oxide synthase; PAI-1, plasminogen activator inhibitor-1.
} 
HS content, reduced anticoagulant properties of HS, and increased PAI-1 secretion disorganized the endothelial matrix, and promoted fibrin formation and vascular damage. This points to DD as an important factor in the development of vascular disorders.

Fibrin split product D-dimer (DD) is thought to be involved in the development of vascular disorders, and its level increases gradually with increasing severity of peripheral vascular sclerosis (van der Bom et al., 2001). The mechanism of a possible DD effect remains unclear, although this soluble fibrin-derived molecule is known to exert distinct biological effects in various cell types, including the endothelium. It alters cell adhesion and spreading, modifies the cytoskeleton and influences the system of plasminogen activation (Herrick et al., 1999). It is believed that such phenotypic alterations are accompanied by changes in the properties and accumulation of the glycosaminoglycan (GAG) component of extracellular matrix (ECM). However, the effect of DD on endothelial GAGs has not been studied.

Heparan sulphate (HS) is of particular importance because endothelial cells produce the anticoagulant HS, which directly modulates the coagulation/fibrinolysis balance by binding to antithrombin (AT). It was demonstrated that this binding is regulated by endogenous NO production (Irokawa et al., 1997), which, in turn, is down-regulated by fibrin degradation products, including DD (Freedman et al., 1995). Therefore, it was of interest to study the effect of DD on the accumulation and properties of endothelial pericellular HS, monitoring simultaneously the level of NO. On the other hand, it seemed important to estimate the secretion of plasminogen activator inhibitor-1 (PAI-1), which is the main regulator of the plasminogen activation system and also reflects the general degradation potential of endothelial matrix (Menashi et al., 1993).

In the present study we have demonstrated that DD reduced the accumulation of endothelial pericellular HS and affected its properties, including the ability to bind to antithrombin.
It is suggested that the decrease of NO level is responsible for HS impairment. In contrast, the DD-induced stimulation of PAI-1 secretion was not mediated by endogenous NO. These properties of DD indicate that it is an active and important component in the development of vascular disorders.

\section{MATERIALS AND METHODS}

Cell culture medium DMEM/F12 and fetal calf serum (FCS) were purchased from Gibco. The necessary additives for culturing, including endothelial cell growth factor (ECGF), trypsin-EDTA solution for endothelial cells, and phenol red-free M199 medium were from Sigma. Trypsin, soybean trypsin inhibitor, chondroitinase $\mathrm{ABC}$ and $\mathrm{AC}$, heparinase I, orgelase, cetylpiridinium chloride, antithrombin (III)-agarose, 2,2' -azinobis-3-ethylbenzthazoline-6-sulphonic acid, L-arginine, L-ascorbic acid, bradykinin, $N^{\omega}$-methyl-L-arginine, plasminogen, tissue plasminogen activator, thrombin, and aprotinin were also purchased from Sigma. Sephadex G-50 and G-25 were from Pharmacia. Hyaluronic acid-K-salt was from Fluka Chemie AG, pronase E from Merck, and DEAE-cellulose (cap. 0.54) from Serva. PAI-1 antigen and goat antibodies were purchased from American Diagnosticum, swine peroxidase-conjugated secondary antibody was from Chemicon. $\left[2-{ }^{14} \mathrm{C}\right]$ acetate $\cdot \mathrm{Na}$ (sp. act. $0.69 \mathrm{Ci} / \mathrm{mmole}$ ) was from Isotop (Russia) and D-[1- $\left.{ }^{3} \mathrm{H}\right]$ glucosamine hydrochloride (sp. act. $3.1 \mathrm{Ci} / \mathrm{mmole}$ ) from Amersham Int. All other chemicals used were of the highest quality available.

Cell culture. Primary endothelial cultures from rabbit coronary arteries were kindly provided by Dr. T. Kovalenko (Institute of Physiology, Kyjv). Cells were passaged with trypsinEDTA and were grown on gelatin-coated 
dishes in DMEM/F12 medium, supplemented with $15 \%$ FCS, $0.5 \%$ ECGF, $90 \mu \mathrm{g} / \mathrm{ml}$ heparin, $2 \mathrm{mM}$ glutamine, $50 \mathrm{U} / \mathrm{ml}$ penicillin, $50 \mu \mathrm{g} / \mathrm{ml}$ streptomycin and $1 \mu \mathrm{g} / \mathrm{ml}$ amphotericin B.

Experimental procedure. All experiments were performed with the 4 th or 5 th passages of culture. Endothelial cells were allowed to reach confluence $\left(4.5-5.5 \times 10^{4}\right.$ cells $\left./ \mathrm{cm}^{2}\right)$ and were then transferred for $24 \mathrm{~h}$ to the heparin-free (Miller et al., 1998), serum-rich (25\% FCS) (Crook et al., 2000), phenol red-free medium M199 (L-arginine concentration was adjusted to that in DMEM/F12). Cells were then extensively washed and exposed to DD $(0-3.0 \mu \mathrm{M})$, in the serum-deprived M199 medium, with $7.0 \mu \mathrm{Ci} / \mathrm{ml}\left[{ }^{14} \mathrm{C}\right]$ acetate or 10.0 $\mu \mathrm{Ci} / \mathrm{ml}\left[{ }^{3} \mathrm{H}\right]$ glucosamine for $48 \mathrm{~h}$. Some subsets of cells were incubated with $30 \mu \mathrm{M}$ $N^{\omega}$-methyl-L-arginine (L-NMMA), or with $50 \mu \mathrm{M}$ L-ascorbic acid (an activator of NO synthesis (Huang et al., 2000) with or without 1.5 $\mu \mathrm{M}$ DD. Some cells were also stimulated by treatment with $0.5 \mu \mathrm{M}$ bradykinin for $1 \mathrm{~h}$.

Cell viability was $>95 \%$, as determined by the trypan blue exclusion test. Cell monolayers were used for the preparation of the cell-associated GAGs concentrations of PAI-1 and nitrite were determined in the conditioned medium.

Methods. The purity of human D-dimer (Marder et al., 1976) was checked by electrophoresis.

The preparation and identification of pericellular GAGs was performed, as described previously (Yevdokimova \& Yefimov, 2001). Briefly, the trypsin-released material was digested by pronase E. Different groups of GAGs were separated on DEAE-cellulose by stepwise elution with $0.28,0.4$ and $0.7 \mathrm{M} \mathrm{NaCl}$ in $0.01 \mathrm{M}$ Tris/ $\mathrm{HCl}, \mathrm{pH}$ 8.4. Estimation of $\left[{ }^{14} \mathrm{C}\right]$ acetate incorporation separately into CS and DS was performed by chondroitinase AC (EC 4.2.2.5) digestion of the fractions corresponding to CS/DS. The radioactivity remaining after digestion represented ${ }^{14} \mathrm{C}$-DS, while the difference between initial radioactivity and ${ }^{14} \mathrm{C}-\mathrm{DS}$ was ascribed to ${ }^{14} \mathrm{C}-\mathrm{CS}$.
The effective concentrations of DD $(0-3 \mu \mathrm{M})$ were determined by measuring the incorporation of $\left[{ }^{3} \mathrm{H}\right]$ glucosamine or $\left[{ }^{14} \mathrm{C}\right]$ acetate into total pericellular GAGs (eluted directly with $0.7 \mathrm{M} \mathrm{NaCl}$ ) and into material sensitive to heparinase I (EC 4.2.2.8).

In order to study the properties of HS under DD treatment, the chromatographic fractions, corresponding to HS were pooled, desalted and concentrated with Centriprep-3 (Whatman). Deaminative cleavage of the ${ }^{14} \mathrm{C}-\mathrm{HS}$ by $\mathrm{HNO}_{2}$ was carried out at $\mathrm{pH} 1.5$ and 3.9. In the first case equal volumes of the ${ }^{14} \mathrm{C}-\mathrm{HS}$ sample (supplemented with $50 \mu \mathrm{g} / \mathrm{ml}$ heparin) and $2 \mathrm{M} \mathrm{HNO}_{2}$ were mixed and incubated for $15 \mathrm{~min}$ at $20^{\circ} \mathrm{C}$ (Shivley \& Conrad, 1976). The reaction was stopped by saturation with $\mathrm{NaHCO}_{3}$. One $\mathrm{ml}$ of the mixture $\left(>15 \times 10^{4}\right.$ d.p.m.) was loaded onto Sephadex G-25 (fine) column $(0.95 \times 100 \mathrm{~cm})$ and eluted with $0.5 \mathrm{M}$ $\mathrm{NH}_{4} \mathrm{HCO}_{3}$ at $4 \mathrm{ml} / \mathrm{h}$. One $\mathrm{ml}$ fractions were analyzed for the radioactivity.

In the second case ${ }^{14} \mathrm{C}-\mathrm{HS}$ was cleaved at $\mathrm{pH}$ 3.9 by $0.24 \mathrm{M} \mathrm{NaNO}_{2}$ in $1.8 \mathrm{M} \mathrm{CH}_{3} \mathrm{COOH}$ for 2 $\mathrm{h}$ at $20^{\circ} \mathrm{C}$ (Lindahl et al., 1973). At pH 3.9 $\mathrm{HNO}_{2}$ cleaves $\mathrm{HS}$ at unsubstituted glucosamine residues $\left(\mathrm{GlcNH}_{2}\right)$, and the reaction products were analyzed by exclusion Sephadex G-50 (fine) chromatography. One ml samples were loaded onto $10 \mathrm{ml}$ columns and eluted with $0.1 \mathrm{M}$ Na-acetate buffer, pH 5.0. The radioactivity of the high mass molecular fraction was subtracted from the radioactivity of the total sample and expressed in percent of the latter.

Binding of ${ }^{14} \mathrm{C}-\mathrm{HS}$ to antithrombin (AT)-agarose was determined according to (Mertens et $a l .$, 1992) with some modifications. AT-agarose beads were swollen in $0.01 \mathrm{M}$ Tris $/ \mathrm{HCl}$, $0.05 \mathrm{M} \mathrm{NaCl}, 0.01 \mathrm{M} \mathrm{MgCl}_{2}, \mathrm{pH}$ 7.4, overnight at $10^{\circ} \mathrm{C} .{ }^{14} \mathrm{C}$-HS sample $\left(>3.5 \times 10^{4}\right.$ d.p.m. $)$ was incubated with AT-agarose in the same buffer, supplemented with $0.01 \%$ Triton X-100 and $25 \mu \mathrm{g} / \mathrm{ml}$ exogenous heparin for $4 \mathrm{~h}$ at $20^{\circ} \mathrm{C}$ with constant shaking. The beads were washed by incubation (for $30 \mathrm{~min}$ ) and centrifugation (500 g, $5 \mathrm{~min}$ ) successively in 
0.05, 0.2 and 0.4 M NaCl. Specifically bound

${ }^{14} \mathrm{C}$-HS was eluted from AT-agarose beads by incubation in $2.0 \mathrm{M} \mathrm{NaCl}$ for $3 \mathrm{~h}$. The beads were centrifuged, the supernatant was dialyzed for $24 \mathrm{~h}$ against $0.01 \mathrm{M}$ Tris/ $\mathrm{HCl}, \mathrm{pH}$ 7.4 , and used for determination of the radioactivity. The AT-bound fraction was expressed in percent of total ${ }^{14} \mathrm{C}$-HS.

Determination of PAI-1 in endothelial conditioned medium was carried out by ELISA. The optimal dilution of goat antibodies for PAI-1 detection was found to be $1: 400$, and the dilution of swine peroxidase-conjugated secondary antibody was 1:800. The reaction was detected with 2,2'-azinobis-3-ethylbenzthazoline-6-sulphonic acid at $405 \mathrm{~nm}$.

NO production was determined by measuring the nitrite concentration in the conditioned medium without protease inhibitors by the Greiss reaction (Green et al., 1982).

Statistical analysis. Results were compared using unpaired $t$-test. $P$ values of $<0.05$ were regarded as significant.

\section{RESULTS}

Incorporation of $\left[{ }^{3} \mathrm{H}\right]$ glucosamine and $\left[{ }^{14} \mathrm{C}\right]$ acetate into pericellular GAGs showed that this component of ECM of normal rabbit aortic endothelial cells contained mainly heparan sulfate (HS) and chondroitin/ dermatan sulfate (CS/DS) (Fig. 1). The incorporation of both precursors into hyaluronic acid (HA) was less than $20 \%$ of total radioactivity. These results are consistent with the data on synthesis of mainly sulphated GAGs by endothelial cells of various origin (Kennedy et al., 1986; Amanuma \& Mitsui, 1991).

DD administration (Fig. 2, panel A) evidently altered the incorporation of $\left[{ }^{3} \mathrm{H}\right]$ glucosamine and $\left[{ }^{14} \mathrm{C}\right]$ acetate into total pericellular GAGs, and at 1.5-3.0 $\mu \mathrm{M}$ DD it was reduced by $20 \%$ of control. The similar dynamics of $\left[{ }^{14} \mathrm{C}\right]$ acetate and $\left[{ }^{3} \mathrm{H}\right]$ glucosamine incorporation into GAGs allows to exclude the possibility of DD influence on acetate or glucosamine

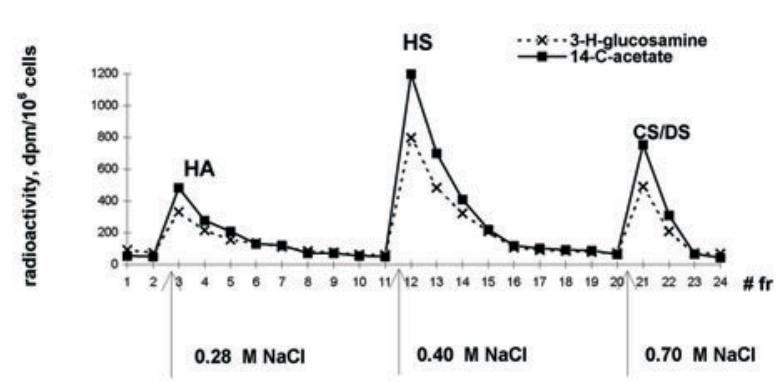

Figure 1. DEAE-cellulose chromatography of pericellular GAGs of rabbit endothelial cells labeled with $\left[{ }^{3} \mathrm{H}\right]$ glucosamine or $\left[{ }^{14} \mathrm{C}\right]$ acetate.

Confluent monolayers of aortic endothelial cells were incubated in M199 medium with $10.0 \mu \mathrm{Ci} / \mathrm{ml}$

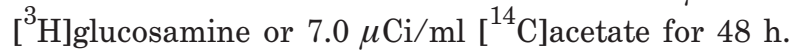
Pericellular GAGs were isolated and fractionated as described in Materials and Methods.

transport. It should also be noted that DD did not alter the confluent monolayer density of endothelial cells which was $51856 \pm 4150$ cells $/ \mathrm{cm}^{2}(\mathrm{n}=8)$ at $3.00 \mu \mathrm{M} \mathrm{DD}$ and $47575 \pm$ 2415 cells $/ \mathrm{cm}^{2}(\mathrm{n}=12)$ in control.

In order to identify GAGs types responding to DD treatment, the samples of total $\left[{ }^{3} \mathrm{H}\right] \mathrm{GAG}$ and $\left[{ }^{14} \mathrm{C}\right] \mathrm{GAGs}$ were digested with heparinase I. As can be seen from panel B of Fig. 2, DD-induced changes in $\left[{ }^{14} \mathrm{C}\right]$ acetate and $\left[{ }^{3} \mathrm{H}\right]$ glucosamine incorporation into heparinase I-sensitive component of GAGs are similar to the alterations of total GAGs level. On the basis of these results we have used DD 1.5 at $\mu \mathrm{M}$ concentration for further experiments.

Incorporation of $\left[{ }^{14} \mathrm{C}\right]$ acetate label into GAGs fractions obtained by DEAE-cellulose chromatography (cf. Fig. 1) confirmed that DD affected exclusively HS, while incorporation into HA, CS and DS remained unaltered (Fig. 3).

The changes of pericellular HS structure under DD treatment were investigated on the basis of the degradation of ${ }^{14} \mathrm{C}-\mathrm{HS}$ by $\mathrm{HNO}_{2}$ at $\mathrm{pH} 1.5$ and $\mathrm{pH}$ 3.9. Since $\mathrm{HNO}_{2}$ at $\mathrm{pH} 1.5$ specifically cleaves $\mathrm{HS}$ at $N$-sulpho-D-glucosamine residues $\left(\mathrm{GlcNSO}_{3}\right)$, leaving $N$-acetyl-D-glucosamine residues (GlcNAc) unaltered, it is possible to evaluate the degree of $\mathrm{N}$-sulphation. 

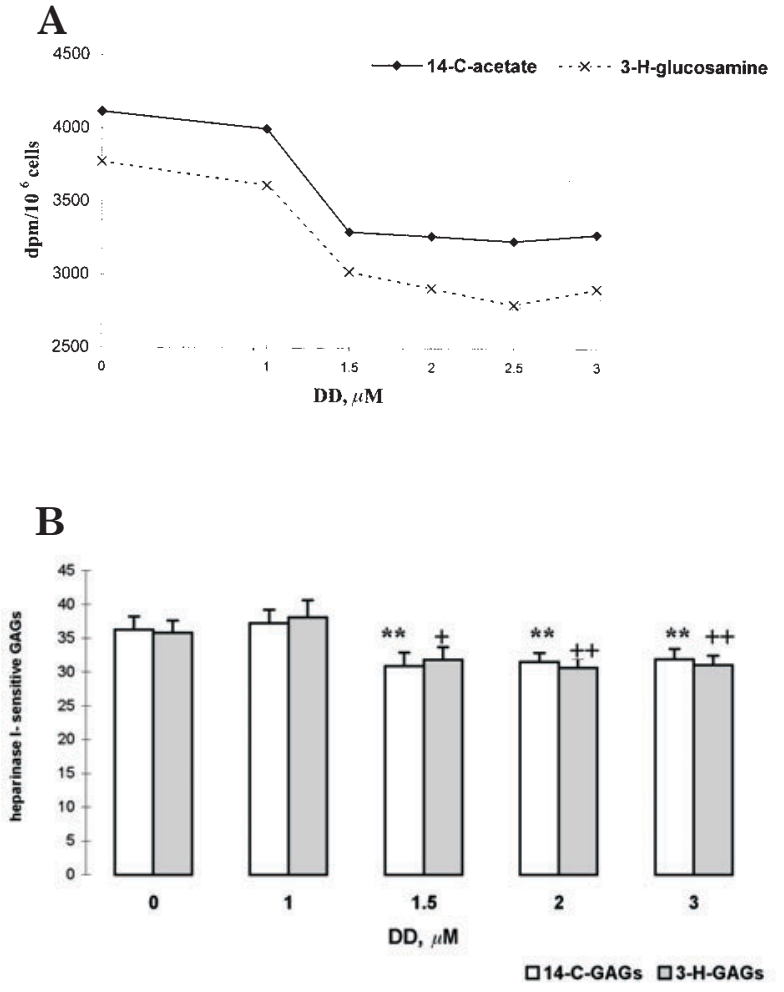

Disaccharides are released from the regions of the polymer chain with contiguous $\mathrm{N}$-sulphated disaccharide units, whereas tetrasaccharides (and higher oligosaccharides) are obtained from the regions with GlcNAc residues. The results of Sephadex

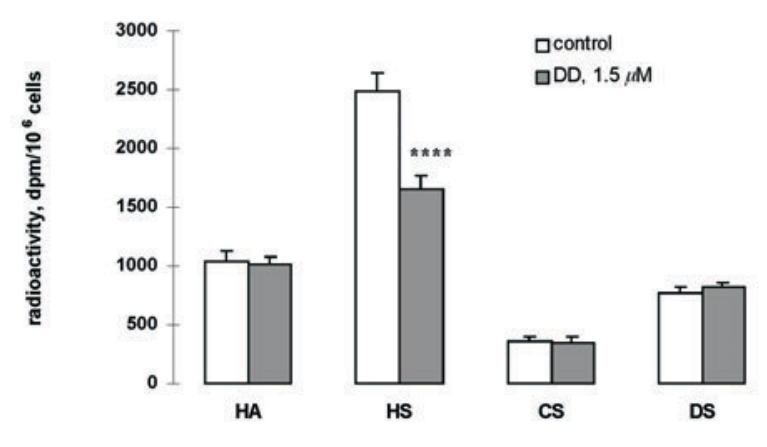

Figure 3. Effect of D-dimer (DD) on $\left[{ }^{14} \mathrm{C}\right]$ acetate incorporation into hyaluronic acid (HA), heparan sulphate (HS), chondroitin sulphate (CS) and dermatan sulphate (DS) of pericellular GAGs of confluent endothelial cells.

$\left[{ }^{14} \mathrm{C}\right] \mathrm{GAGs}$ were separated as described in Materials and Methods. Data are expressed as mean \pm S.E. of 3 independent experiments in triplicate. ${ }^{* * * *}$ Significant at $P<0.001$.
Figure 2. Effect of D-dimer (DD) on $\left[{ }^{14} \mathrm{C}\right]$ acetate and $\left[{ }^{3} \mathrm{H}\right]$ glucosamine incorporation into total pericellular GAGs (panel A) and into their heparinase I-sensitive fraction (panel B).

Panel A. Cells were exposed to increasing concentrations $(0-3.0 \mu \mathrm{M})$ of $\mathrm{DD}$ with $10.0 \mu \mathrm{Ci} / \mathrm{ml}$ $\left[{ }^{3} \mathrm{H}\right]$ glucosamine or $7.0 \mu \mathrm{Ci} / \mathrm{ml}\left[{ }^{14} \mathrm{C}\right]$ acetate for $48 \mathrm{~h}$. Total pericellular GAGs were eluted with $0.7 \mathrm{M} \mathrm{NaCl}$. For details see Materials and Methods. Data are expressed as means of 3 experiments in triplicate. S.E. did not exceed $10 \%$ of the means. Panel B. Samples of total pericellular $\left[{ }^{14} \mathrm{C}\right] \mathrm{GAGs}$ or $\left[{ }^{3} \mathrm{H}\right] \mathrm{GAGs}$ of DD-treated cells were subjected to heparinase I digestion. The difference between initial and residual radioactivity was referred to as HS. Data are represented in $\%$ of total $\left[{ }^{14} \mathrm{C}\right] \mathrm{GAGs}$ or $\left[{ }^{3} \mathrm{H}\right] \mathrm{GAGs}$ and are expressed as mean \pm S.E. of 4 replicates. ${ }^{* *}$ Significant at $P<0.02$, *significant at $P<0.05$, as compared to control $\left[{ }^{14} \mathrm{C}\right] \mathrm{GAGs},{ }^{++}$significant at $P<0.02,{ }^{+}$significant at $P$ $<0.05$, as compared to control $\left[{ }^{3} \mathrm{H}\right] \mathrm{GAG}$.

G-25 fractionation of the HS cleavage products showed that the radioactivity was redistributed from peak I to peaks II and III in the cells treated with $1.5 \mu \mathrm{M}$ DD (Fig. 4).

For statistical processing the fractions of peaks I (No. 32-40), II (No. 44-48), and III (No. 53-56) from each sample were combined and expressed in percent of total ${ }^{14} \mathrm{C}-\mathrm{HS}$ (Table 1). The differences are significant and proved the increased degree of $\mathrm{N}$-sulphation upon DD treatment.

At pH $3.9 \mathrm{HNO}_{2}$ cleaves HS at unsubstituted glucosamine residues $\left(\mathrm{GlcNH}_{2}\right)$. As can be seen from Fig. 5 the level of N-unsubstitution of HS is increased in the DD-treated endothelial cells, as compared to control cells.

Moreover, the DD effect on HS structure involves its binding to AT-agarose.

DD decreased the basal level of nitrite in the conditioned medium, but bradykinin stimulated NO production by the control and DD-treated cells to the same extent (about 1.6-fold, not shown), indicating the preserved response of endothelial NO synthase (eNOS) upon DD treatment. 
L-NMMA, a known competitive inhibitor of NO synthesis, suppressed nitrite formation to the level, comparable to the effect of $1.5 \mu \mathrm{M}$ $\mathrm{DD}$, decreasing at the same time the incorporation of $\left[{ }^{14} \mathrm{C}\right]$ acetate into HS (Table 2) without affecting incorporation of the label into more NO (Table 2), and accumulated more ${ }^{14} \mathrm{C}$-HS in pericellular matrix (Table 2) in comparison to the cells treated only with DD. L-Ascorbic acid decreased the level of N-unsubstitution of HS (Fig. 5, Table 2), increased HS-AT binding (Fig. 5, Table 2) and al-

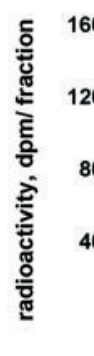

Figure 4. Sephadex G-25 fractionation of oligosaccharides released by $\mathrm{HNO}_{2}$ cleavage at $\mathrm{pH}$ 1.5 of ${ }^{14} \mathrm{C}-\mathrm{HS}$ of control and D-dimer (DD)-treated endothelial cells.

The preparation of ${ }^{14} \mathrm{C}$-HS samples

k and chromatography was as de-

No. scribed in Materials and Methods.

HA, CS and DS (not shown). Moreover, the L-NMMA-treated cells produced HS with an increased degree of $\mathrm{N}$-sulphation (Tables 1 and 2) and N-unsubstitution (Table 2), and with a decreased ability to bind to AT-agarose (Table 2).

It is known that L-ascorbic acid enhances NO production, without influencing the expression of eNOS (Huang et al., 2000). The endothelial cells, which were exposed simultaneously to DD and L-ascorbic acid, produced

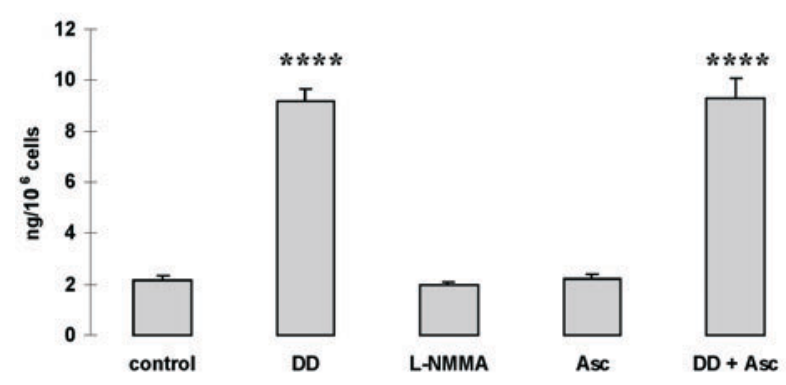

Figure 5. PAI-1 secretion by endothelial cells.

Confluent endothelial cells were exposed to 1.5 $\mu \mathrm{M}$ of DD, $30 \mu \mathrm{M} \mathrm{N}$-methyl-L-arginine (L-NMMA), $50 \mu \mathrm{M}$ L-ascorbic acid (Asc) and $1.5 \mu \mathrm{M}$ of DD + 50 $\mu \mathrm{M}$ L-ascorbic acid. Concentration of PAI-1 in the conditioned medium was determined by ELISA, as described in Materials and Methods. Data are expressed as means \pm S.E. of 2 independent experiments in triplicate. ${ }^{* * *}$ Significant at $P<0.001$, *** significant at $P<0.01$, as compared to control. most normalized the level of N-sulphation (Tables 1 and 2).

For comparison purposes we have demonstrated the up-regulation of PAI-1 secretion by DD (Fig. 5). In contrast to the normalizing effect of L-ascorbic acid on HS level and its properties in the DD-treated cells, PAI-1 secretion remained unchanged. Endothelial cells did not respond either to L-NMMA or to L-ascorbic acid in terms of PAI-1 secretion.

\section{DISCUSSION}

DD is a product of the cross-linked fibrin degradation by the fibrinolytic system. The elevated plasma $D D$ seems to be a marker of a systemic prothrombotic state, and application of anticoagulant therapy can normalize its level. It has been proposed that DD may predict vascular complications, particularly in cases, when its high level is associated with an elevated level of prothrombin fragment $1+2$ versus the normal level of the thrombin-AT complexes. Such alterations are observed in systemic sclerosis (Ames et al., 1997), antiphospholipid syndrome (Ames et al., 1996), and diabetes mellitus (Gruden et al., 1993), i.e., disorders with evident micro- and macrovascular pathology. These phenomena 
Table 1. Distribution of oligosaccharides formed by $\mathrm{HNO}_{2}$ cleavage at $\mathrm{pH} 1.5$ of $\mathrm{HS}$ (\% of total ${ }^{14}$ C-HS)

\begin{tabular}{llllll}
\hline Size class & Peak $^{\mathrm{a}}$ & Control & DD & L-NMMA & DD+Asc \\
\hline Di- & III & $20.2 \pm 1.7$ & $26.9 \pm 1.5^{*}$ & $27.0 \pm 2.5^{*}$ & $23.1 \pm 2.2$ \\
Tetra- & II & $22.6 \pm 1.9$ & $28.2 \pm 1.8^{*}$ & $29.9 \pm 2.6^{*}$ & $25.9 \pm 2.5$ \\
Higher & I & $57.2 \pm 5.6$ & $44.9 \pm 2.3^{* * *}$ & $43.1 \pm 3.9^{* *}$ & $51.0 \pm 4.8^{*}$ \\
\hline
\end{tabular}

HS was isolated from the pericellular matrix of endothelial cells treated with $1.5 \mu \mathrm{M}$ DD, $30 \mu \mathrm{M}$ L-NMMA and $1.5 \mu \mathrm{M}$ DD +50 $\mu \mathrm{M}$ L-ascorbic acid (Asc). It was cleaved by $\mathrm{HNO}_{2}$ at $\mathrm{pH}$ 1.5. The fragments obtained were separated by Sephadex G-25 chromatography. Data represent the $\%$ of the radioactivity of total ${ }^{14} \mathrm{C}-\mathrm{HS}$ for each sample, and are expressed as means $\pm \mathrm{S}$.E. of 2 independent experiments in triplicate. Experiments with L-ascorbic acid were done in duplicate. ${ }^{* * *}$ Significant at $P<0.01,{ }^{* *}$ significant at $P<0.02$, * significant at $P<0.05$, as compared to control. ${ }^{\mathrm{a}}$ Fig. 4.

are interpreted as due to the impaired function of the anticoagulant HS-AT system, possibly as a result of anti-endothelial cell antibodies, which may hinder AT-HS binding, or, in the case of diabetes, additionally due to the down-regulation of HS by a high glucose level
It is known that various metabolic products may directly affect the accumulation and structure of HS chains during their initial formation or recycling (Prydz \& Dalen, 2000). According to our data, DD inhibits NO production by endothelial cells which is in line with

Table 2. The accumulation and properties of pericellular HS in comparison with NO production in rabbit coronary endothelial cells

\begin{tabular}{llll}
\hline & DD & L-NMMA & DD + Asc \\
\hline HS accumulation & $68.3 \pm 5.9^{* * * *}(\mathrm{n}=15)$ & $76.5 \pm 6.4^{* * *}(\mathrm{n}=9)$ & $91.3 \pm 8.7(\mathrm{n}=6)$ \\
N-unsubstitution & $130.8 \pm 12.1^{*}(\mathrm{n}=7)$ & $138.7 \pm 14.2^{* *}(\mathrm{n}=6)$ & $108.8 \pm 10.1(\mathrm{n}=6)$ \\
N-sulphation & $129.5 \pm 12.1^{*}(\mathrm{n}=6)$ & $133.1 \pm 13.0^{* *}(\mathrm{n}=6)$ & $112.5 \pm 11.8(\mathrm{n}=4)$ \\
AT-binding & $56.6 \pm 5.4^{* * *}(\mathrm{n}=9)$ & $62.3 \pm 5.9^{* * *}(\mathrm{n}=7)$ & $87.1 \pm 8.0(\mathrm{n}=6)$ \\
NO concentration & $62.9 \pm 6.1^{* * *}(\mathrm{n}=12)$ & $58.1 \pm 5.5^{* * *}(\mathrm{n}=8)$ & $96.0 \pm 9.6(\mathrm{n}=6)$ \\
\hline
\end{tabular}

Confluent endothelial cells were exposed to $1.5 \mu \mathrm{M}$ of DD, $30 \mu \mathrm{M} N^{\omega}$-methyl-L-arginine (L-NMMA), and $1.5 \mu \mathrm{M}$ of DD $+50 \mu \mathrm{M}$ L-ascorbic acid (Asc). HS was prepared and cleaved by $\mathrm{HNO}_{2}$ at $\mathrm{pH} 3.9$ as described in Materials and Methods. The difference between radioactivity of $\mathrm{HS}$ samples before (total ${ }^{14} \mathrm{C}-\mathrm{HS}$ ) and after cleavage represented the N-unsubstituted GlcH $\mathrm{H}_{2}$ residues, and was expressed in percent of total ${ }^{14} \mathrm{C}-\mathrm{HS}$. Control value was $4.99 \pm 0.48 \%(\mathrm{n}=8)$. Binding of pericellular ${ }^{14} \mathrm{C}-\mathrm{HS}$ of endothelial cells to AT-agarose is described in Materials and Methods. Specifically bound fraction of ${ }^{14} \mathrm{C}-\mathrm{HS}$ was represented in percent of total ${ }^{14} \mathrm{C}-\mathrm{HS}$. Control value is $3.17 \pm 0.27 \%(\mathrm{n}=9)$. The NO production was expressed as nitrate concentration in the conditioned medium, and the control value was $54.9 \pm 0.51$ pmole $/ 10^{6}$ cells $(n=10)$. The alterations of $\mathrm{N}$-sulphation degree were calculated from data on the radioactivity of peak I (Fig. 4). Data represent the \% of the control for each sample, and are expressed as mean \pm S.E. ${ }^{* * *}$ Significant at $P<0.01,{ }^{* *}$ significant at $P<0.02$, ${ }^{*}$ significant at $P<0.05$, as compared to control.

(van Det et al., 1996). The effects of DD in vitro (Herrick et al., 1999) allow to assume its direct participation in the development of vascular disorders.

In this study we have demonstrated that DD decreased the content of HS in pericellular matrix of endothelial cells, and impaired the structure and the anticoagulant properties of HS. We propose the following explanation of the observed phenomena. the down-regulation of eNOS mRNA expression (Freedman et al., 1995). The reduction of NO concentration was shown to have two direct effects on the level and properties of pericellular HS. On the one hand, a low NO level inhibits the physiological desaminative cleavage of $\mathrm{HS}$ at unsubstituted $\mathrm{GlcNH}_{2}$ (Vilar et al., 1997; Ding et al., 2001) which is manifested by the increased content of HS with $\mathrm{N}$-unsubstituted chains. On the other 
hand, NO shortage causes a dose-response development of intracellular oxidative stress in endothelial cells (Kurose et al., 1995; Irokawa et al., 1997), and induces the release of reactive oxygen species (ROS) into the extracellular compartment (Niu et al., 1996). ROS depolymerize HS in vitro (Moseley et al., 1995) and in vivo (Okasora et al., 1992) at the low-sulphated regions of the molecule, without affecting the high-sulphated regions. Therefore, the total amount of pericellular HS decreases, but the amount of sulphate groups increases. The data given in Table 2 show that the DD influence on the accumulation and properties of pericellular HS and NO production correspond to the above mentioned effects of the reduction of NO level.

Moreover, we have demonstrated that DD reduced the anticoagulant fraction of HS. It is known that anticoagulant HS contains a pentasaccharide sequence, which is responsible for specific HS binding to AT. The increased $\mathrm{N}$-sulphation of this sequence was shown to inhibit AT-anticoagulant HS binding (Kovensky et al., 1990; Gallagher, 1997). Thus the increase of $\mathrm{N}$-sulphation and simultaneous decrease of AT binding under DD treatment are consistent with these data.

It can also be seen from Table 2 that the L-NMMA-induced inhibition of NO production associated with the decreased accumulation of pericellular $\mathrm{HS}$ and deterioration of its properties resembles the effect of $1.5 \mu \mathrm{M}$ DD. And, at last, the addition of L-ascorbic acid to the DD-treated cells enhancing the activity of eNOS, to abolished the reduction of nitrite concentration, recovers the $\left[{ }^{14} \mathrm{C}\right]$ acetate incorporation into $\mathrm{HS}$, decreasing its $\mathrm{N}$-unsubstitution and $\mathrm{N}$-sulphation and improving $\mathrm{HS}$ binding to AT.

We suppose, therefore, that the inhibition of NO production by DD promotes the development of oxidative stress and generation of ROS, which, in turn, destroy the low-sulphated regions of HS chains, inhibit HS accumulation in pericellular matrix and diminish its anticoagulant properties.
Another possible mechanism, which may mediate the effect of the DD-induced inhibition of nitrite production on HS level may involve activation of the transcription nuclear factor (NF)- $\kappa \mathrm{B}$ signalling by ROS (True et al., 2000) and, hence, heparanase activation (Andela et al., 2000). Heparanase is known to degrade $\mathrm{HS}$ at various sites but particularly cleaves its AT binding pentasaccharide (Vlodavsky \& Friedman, 2001). This leads to the decreased accumulation of HS and decreased AT-HS binding, which we observed on DD administration.

The $\gamma 117-133$ sequence is exposed in DD, and its specific binding to intercellular adhesion molecule-1 (ICAM-1) (Harley \& Powell, 1999) determines the interaction of DD with endothelial cells. ICAM-1 is down-regulated in endothelial cells cultured in their basic medium M 199 (Miller et al., 1998; Crook et al., 2000). The cells must be activated in the serum-rich, heparin-free medium to reveal a significant response to DD in terms of NO production and HS accumulation.

DD stimulates the secretion of PAI-1, but this effect is hardly connected to the inhibition of endogenous NO production, because neither L-NMMA nor L-ascorbic acid have any effect on basal or DD-stimulated PAI-1 secretion. Our data, therefore, confirm the lack of response of basal PAI-1 secretion in endothelial cells to the increased level of endogenous NO (Swiatkowska et al., 2000). Besides, we could detect the effect of DD on PAI-1 secretion irrespective of cell activation (not shown). This casts doubts on the participation of ICAM-1 in cell response to DD in terms of PAI-1 secretion, and corresponds to the results of Olman et al. (1999), who showed that in fibroblasts DD induces transcription of PAI-1 through the definite, highly conserved, region of PAI-1 gene promoter. These authors suppose that DD possesses conformationally dependent signaling epitopes that regulate PAI-1 expression, which may be exposed upon plasmin cleavage of a cross-linked fibrin in a manner similar to that seen with thrombin 
cleavage of fibrinogen. Potential DD epitopes have yet to be characterized.

Thus, on the one hand, the DD-induced stimulation of PAI-1 secretion inhibits plasminogen activation, and, hence, may have a compensatory action, decreasing HS shedding (Bernfield, 1999) and blocking fibrinolysis and DD formation. However, at the same time an inactive plasmin decreases the activity of specific matrix metalloproteinases (Menashi et $a l .$, 1993) and promotes fibrin deposition, which is known to have profibrotic properties (Senior et al., 1986). On the other hand, and, very likely due to another mechanism, DD inhibits the binding of anticoagulant HS to AT, leading to inadequate thrombin neutralization and excessive fibrin formation. Thrombin, like fibrin, not only possesses profibrotic properties (Dawes et al., 1993), but, like plasmin, can catalyse HS shedding (Bernfield, 1999). Moreover, if fibrin degradation does occur (because of reasons apart from DD inhibition of PAI-1 production), it causes an increase in DD production, forming a vicious circle. Thus, taking into the account the above aspects of DD action it facilitates formation of fibrin and thrombin, which damage endothelial cells, attracts fibroblasts and stimulates their proliferation. The loss of HS of endothelial ECM disturbs the metabolic action of various growth factors and alters the permeability of the endothelial monolayer to large molecules. All the above events take place during decreased NO production, which not only prevents vasodilation, but down-regulates the expression of integrin $\alpha v \beta 3$, facilitating endothelial cell survival (Murohara et al., 1998). Hence, all consequences of DD influence on endothelial cells, either directly or via the coagulation/fibrinolysis system, contribute to the development of vascular malfunction.

\section{R E F E R E N C E S}

Amanuma K, Mitsui Y. (1991) Hyaluronic acid synthesis is absent in normal human endo- thelial cells irrespective of hyaluronic acid synthetase inhibitor activity but is significantly high in transformed cells. Biochim Biophys Acta.; 1092: 336-40.

Ames P, Ivannaccone L, Tomassino C, Brillante M, Cimino R, Brancaccio V. (1996) Coagulation activation and fibrinolytic imbalance in subjects with idiopatic antiphospholipid antibodies. Thromb Haemost.; 76: 190-4.

Ames P, Lupoli S, Alves J, Atsumi T, Edwards C, Iannaccone I, Khamashta M, Huges G, Brancaccio V. (1997) The coagulation/ fibrinolysis balance in systemic sclerosis: evidence for a haematological stress syndrome. Br J Reumatol.; 36: 1045-50.

Andela VB, Schwarz EM, Puzas JE, O’Keefe RJ, Rosier RN. (2000) Tumor metastasis and the reciprocal regulation of prometastatic and antimetastatic factors by nuclear factor $\kappa \mathrm{B}$. Cancer Res.; 60: 6557-62.

Bernfield M. (1999) Functions of cell surface heparan sulphate proteoglycans. Ann Rev Biochem.; 68: 729-77.

van der Bom JG, Bots ML, Haverkate F, Meijer P, Hofman A, Kluft C, Grobbee DE. (2001) Activation products of the haemostatic system in coronary cerebrovascular and peripheral arterial disease. Thromb Haemost.; 85: 234-9.

Crook MF, Newby AC, Southgate KM. (2000) Expression of intercellular adhesion molecules in human saphenous veins: effects of inflammatory cytokines and neointima formation in culture. Atherosclerosis.; 150: 33-41.

Dawes KE, Gray AJ, Laurent GI. (1993) Thrombin stimulates fibroblast chemotaxis and replication. Eur J Cell Biol.; 61: 126-30.

van Det NF, van den Born J, Tamsma JT. (1996) Effects of high glucose on the production of heparan sulphate by mesangial and epithelial cells. Kidney Int.; 49: 1079-89.

Ding K, Jonsson M, Mani K, Sandgren S, Belting M, Fransson L-A. (2001)

$\mathrm{N}$-unsubstituted glucosamine in heparan sulfate of recycling glypican-1 from suramintreated and nitrite-deprived endothelial cells. J Biol Chem.; 276: 3885-94. 
Freedman JE, Fabian A, Loscazio J. (1995) Impaired EDRF production by endothelial cells exposed to fibrin monomer and FDP. Am $J$ Physiol.; 268: L520-6.

Gallagher JT. (1997) Structure-activity relationship of heparan sulphate. Biochem Soc Transact.; 25: 1206-9.

Green LC, Wagner DA, Glogowski J, Skipper PL, Wishnok JS, Tannebaum SR. (1982) Analysis of nitrate nitrite and $\left[{ }^{15}\right.$ N]nitrate in biological fluids. Anal Biochem.; 126: 131-8.

Gruden G, Cavallo-Perin P, Romagnoli R, Olivetti C, Frezet D, Pagano G. (1993)

Prothrombin fragment $1+2$ and antithrombin III-thrombin complex in microalbuminuric type II diabetic patients. Diabetes Med.; 11: 485-8.

Harley SL, Powell JT. (1999) Fibrinogen up-regulates the expression of monocyte chemoattractant protein 1 in human saphenous vein endothelial cells. Biochem J.; 341: 739-44.

Herrick S, Blanc-Brude O, Gray A, Laurent G. (1999) Fibrinogen. Int J Biochem Cell Biol.; 31: 741-67.

Huang A, Vita JA, Venema RC, Keaney JF. (2000) Ascorbic acid enhances endothelial nitric-oxide synthase activity by increasing intracellular tetrahydrobiopterin. $J$ Biol Chem.; 275: 17399-406.

Irokawa M, Nishinaga M, Ikeda U, Shinoda Y, Suematsu M, Gouda N, Ishimura Y, Shimada K. (1997) Endothelial-derived nitric oxide preserves anticoagulant heparan sulphate expression in cultured porcine aortic endothelial cells. Atherosclerosis.; 135: 9-17.

Kennedy A, Frank RN, Mancini MA. (1986) In vitro production of glycosaminoglycans by retinal microvessel cells and lens epithelium. Invest Ophthalmol Vis Sci.; 27: 746-54.

Kovensky J, Sassetti B, Cirelli F, Kordich A. (1990) Low anticoagulant activity of high sulphated heparan sulphates. Thromb Haemost.; 63: 488-92.

Kurose I, Wolf R, Grisham MB, Aw TY, Specian RD, Granger DN. (1995) Microvascular responses to inhibition of nitric oxide produc- tion. Role of active oxidants. Circ Res.; 76: 30-9.

Lindahl U, Backstrom G, Jansson L, Hallen A. (1973) Biosynthesis of heparin II. Formation of sulfamino groups. J Biol Chem.; 248: 7234-41.

Marder VJ, Budzynski AZ, Barlow GH. (1976) Comparison of the physicochemical properties of fragment $\mathrm{D}$ derivatives of fibrinogen and fragment D-D of cross-linked fibrin. Biochim Biophys Acta.; 427: 1-14.

Menashi S, Lu H, Soria C, Legrand Y. (1993) Endothelial cell proteases: physiological role and regulation. Baillieres Clin Haemotol.; 1: 559-76.

Mertens G, Cassiman J-J, van den Berghe H, Vermylen J, David G. (1992) Cell surface heparan sulfate proteoglycans from human vascular endothelial cells. Core protein characterization and antithrombin III binding properties. J Biol Chem.; 267: 20435-43.

Miller SJ, Hoggat AM, Faulk WP. (1998) Heparin regulates ICAM-1 expression in human endothelial cells: an example of non-cytokine-mediated endothelial activation. Thromb Haemost.; 80: 481-7.

Moseley R, Waddington R, Evans P, Hallwell B, Embery G. (1995) The chemical modification of glycosaminoglycan structure by oxygen-derived species in vitro. Biochem Biophys Acta.; 1244: 245-2.

Murohara T, Witzenbichler B, Spyridopoulos I, Asahara T, Ding B, Sullivan A, Losordo DW, Isner M. (1998) Role of endothelial nitric oxide synthase in endothelial cell migration. Arterioscler Thromb Vasc Biol.; 19: 1156-61.

Niu XF, Ibbotson G, Kubes P. (1996) A balance between nitric oxide and oxidants regulates mast cell-dependent neutrophil-endothelial cell interaction. Circ Res.; 79: 992-9.

Okasora T, Takikawa T, Utsunomiya Y, Senoh I, Hayashibara H, Shiraki K, Kasagi T, Shimizu F. (1992) Suppressive effect of superoxide dismutase on adriamycin nephropathy. Nephron.; 60: 199-203.

Olman MA, Hagood JS, Simmons WL, Fuller GM, Vinson C, White KE. (1999) Fibrin frag- 
ment induction of plasminogen activator inhibitor transcription is mediated by activator protein-1 through a highly conserved element. Blood.; 94: 2029-38.

Prydz K, Dalen KT. (2000) Synthesis and sorting of proteoglycans. J Cell Sci.; 113: 193-205.

Senior RM, Skogen WF, Griffin GL. (1986) Effects of fibrinogen derivatives upon the inflammatory response. J Clin Invest.; 77: 1014-9.

Shivley JE, Conrad HE. (1976) Formation of anhydrosugars in the chemical depolymerization of heparin. Biochemistry.; 15: $3932-42$.

Swiatkowska M, Cierniewska-Cieslak A, Pawlowska Z, Cierniewski CS. (2000) Dual regulatory effect of nitric oxide on PAI-1 expression in endothelial cells. Eur J Biochem.; 267: 1001-7.
True AL, Rahman A, Malik AB. (2000) Activation of NF-kappaB induced by $\mathrm{H}_{2} \mathrm{O}_{2}$ and TNF-alpha and its effects on ICAM-1 expression in endothelial cells. Am J Physiol Lung Cell Mol Physiol.; 279: L302-11.

Vilar LE, Ghael D, Li M, Bhagat DD, Arrigo LM, Cowman MK, Dweck HS, Rosenfeld L. (1997) Nitric oxide degradation of heparin and heparan sulphate. Biochem J.; 324: 473-9.

Vlodavsky I, Friedman Y. (2001) Molecular properties and involvement of heparanase in cancer metastasis and angiogenesis. J Clin Invest.; 108: 341-7.

Yevdokimova N Yu, Yefimov AS. (2001) Effects of wheat germ agglutinin and concanavalin A on the accumulation of glycosaminoglycans in pericellular matrix of human dermal fibroblasts. A comparison with insulin. Acta Biochim Polon.; 48: 563-72. 